\title{
PENDAMPINGAN SISTEM APLIKASI KEUANGAN DAN PENGEMBANGAN PROMOSI DIGITAL UKM "Resep Iboe" DALAM PENERAPAN LESS CONTACT ECONOMY COVID-19
}

\author{
Ratih Apri Utami'), Indah (banah²), Nurul Dwi Novikarumsari²) \\ 1)Program Studi Agribisnis, Fakultas Pertanian, Universitas Jember, KotaJember, Provinsi Jawa Timur, Indonesia \\ ${ }^{2)}$ Program Studi Penyuluhan Pertanian, Fakultas Pertanian, Universitas Jember, Kabupaten Jember, Provinsi Jawa \\ Timur, Indonesia \\ Corresponding author : Ratih Apri Utami \\ E-mail : ratihapri17@unej.ac.id
}

Diterima 27 Oktober 2021, Direvisi 08 November 2021, Disetujui 08 November 2021

\begin{abstract}
ABSTRAK
UKM "Resep Iboe" adalah salah satu Industri Rumah Tangga yang bergerak di bidang pengolahan dan penjualan aneka olahan kue kering tradisional Khas Jember. Lokasi usaha terletak di Desa Karangkedawung Kecamatan Mumbulsari Kabupaten Jember. Permasalahan mitra yang diidentifikasi di UKM "Resep Iboe" adalah pertama pada proses produksi yang selama ini masih bersifat tradisional sehingga produksi yang dihasilkan kurang optimal. Permasalahan kedua yaitu tidak adanya pembukuan keuangan yang terstruktur, sehingga diperlukan pembukuan keuangan melalui sistem keuangan yang terstruktur. Permasalahan ketiga, yaitu akses pemasaran melalui promosi produk belum menyebar luas. Sedangkan di sisi lain UKM "Resep Iboe" diharuskan menyesuaikan dengan kondisi pandemi Covid-19 untuk menerapkan less contact economy, sehingga diperlukan pengembangan digitalisasi pemasaran. Program Pengabdian Kemitraan pada UKM "Resep Iboe" ini merupakan pendampingan kewirausahaan, kelembagaan dan manajemen pemasaran dalam mendukung pengembangan usaha berbasis kelompok. Kegiatan dimulai dengan sosialisasi, dilanjutkan dengan pelatihan inovasi produk (bentuk, rasa, dan kemasan), pelatihan transaksi keuangan (SIAPIK dan QRIS) dan pelatihan desain promosi digital marketing (imooji). Tindak lanjut pasca program dari kegiatan ini adalah menjadikan lokasi pelaksanaan pengabdian sebagai mitra edukasi kewirausahaan, pendampingan manajemen keuangan dan media pemasaran digital. Sedangkan rencana luaran yang ditargetkan: berupa bantuan pendampingan dan peralatan pendukung produksi, pendampingan sistem keuangan SIAPIK serta pembuatan akun platform digital marketing imooji.
\end{abstract}

Kata kunci: UKM; inovasi; SIAPIK; imooji.

\begin{abstract}
SMEs "Resep Iboe" is one of the Home Industries which is engaged in processing and selling various processed traditional Jember pastries. The business location is located in Karangkedawung Village, Mumbulsari District, Jember Regency. The partner problems identified in SMEs "“Resep Iboe"' are the first in the production process which is still traditional so that the resulting production is less than optimal. The second problem is the absence of structured financial bookkeeping, so that financial accounting through a structured financial system is needed. The third problem, namely access to marketing through product promotion has not been widespread. Meanwhile, on the other hand, SMEs "Resep Iboe" are required to adapt to the conditions of the Covid-19 pandemic to implement a less contact economy, so the development of marketing digitalization is needed. The Partnership Service Program for SMEs "Resep Iboe" is an entrepreneurship, institutional and marketing management assistance in supporting group-based business development. The activity started with socialization, followed by product innovation training (shape, taste, and packaging), financial transaction training (SIAPIK and QRIS) and digital marketing promotion design training (imooji). The post-program followup of this activity is to make the location of the service implementation a partner for entrepreneurship education, financial management assistance and digital marketing media. While the planned outputs are targeted: in the form of assistance and production support equipment, assistance to the SIAPIK financial system and the creation of an imooji digital marketing platform account.
\end{abstract}

Keywords: SMEs; innovation; SIAPIK; imooji. 


\section{PENDAHULUAN}

Mitra program pengabdian kemitraan yang diimplementasikan adalah kelompok produktif di UKM yang terdampak COVID-19 bernama Produsen Kue Kering "Resep Iboe". "Resep Iboe" adalah nama suatu Usaha Kecil dan Menengah (UKM) yang bergerak di bidang pengolahan dan penjualan aneka olahan kue kering tradisional yang digemari masyarakat. Didirikan oleh wirausahawan bernama Ami Puji Trisnowati pada tanggal 10 Maret 2019. UKM "Resep Iboe" termasuk Industri Rumah Tangga (IRT) yang belum memiliki badan hukum dengan kepemilikan perseorangan. Lokasi usaha terletak di Desa Karangkedawung Kecamatan Mumbulsari Kabupaten Jember. Pada saat pandemi covid-19 hampir seluruh aspek kehidupan mengalami kelumpuhan. Selain itu pandemi covid-19 ini juga berdampak pada semua sektor perekonomian baik yang berskala besar sampai yang berskala kecil (Nasution, 2020; Amri, 2020). Namun, Nurlinda dan Sinuraya (2020) menyebutkan potensi UMKM juga terlihat pada masa pandemi covid-19 yang masih dapat bertumbuh sebesar $55 \%$. Dimana pertumbuhan ini paling banyak muncul dari usaha kecil yang bergerak dalam bidang kuliner.

Kebiasaan masyarakat saat ini yang serba praktis dan memilih membeli produk yang diinginkan menjadi peluang berkembangnya usaha. UKM "Resep Iboe" "mengunggulkan pengolahan kue kering tradisional yang digemari masyarakat. Kabupaten Jember yang terkenal dengan produk suwar-suwir kini juga mulai dikenal dengan produk kue kacang emprull khas Jember terutama oleh masyarakat Jawa Tengah yang merupakan pasar utama kue kacang. Produk yang dihasilkan memiliki daya saing tersendiri dikarenakan harganya lebih terjangkau dibandingkan kue buatan pabrik. UKM "Resep Iboe" merupakan usaha yang bersifat padat karya sehingga dapat membuka lapangan kerja bagi masyarakat sekitar terutama di era pandemi.

Pengabdian ini merupakan upaya yang dilakukan untuk memberikan pendampingan, pengetahuan dan keterampilan tentang inovasi produk (rasa, bentuk dan kemasan), pencatatan sistem keuangan menggunakan aplikasi digital dan penggunaan booklet digital sebagai sarana promosi yang interaktif. Kegiatan pengabdian diawali dengan pembukaan, perkenalan tim pengusul, penyampaian agenda pendampingan, pelatihan inovasi produk, pendampingan pencatatan sistem keuangan menggunakan aplikasi SIAPIK yaitu aplikasi berbasis Android yang dikeluarkan Bank Indonesia (Marlina, Sumarni, \& Mundzir, 2018), Ada pun transaksi pembayaran digital menggunakan QRIS dan pendampingan brosur digital menggunakan aplikasi imooji. Menurut Arianto (2020), menyebutkan bahwa pengembangan pemasaran digital imooji ini sangat memperhatikan perihal konten kreatif. Konten kreatif menjadi ranah bersaing di era digital utamanya dalam hal promosi pemasaran digital. Namun, hal ini masih sulit pada sebagian besar UMKM Indonesia karena kurangnya pengetahuan akan pembuatan konten kreatif dan masalah pengemasan produk yang ada. Selain itu, sinergi antara penggiat UMKM dan generasi $Z$ sebagai warganet juga menjadi kunci bertahannya usaha UMKM. Generasi Z yang memiliki relasi yang luas juga membantu UMKM tetap bertahan di masa pandemi.

Pendampingan dilakukan dengan menyesuaikan kebutuhan guna mengatasi permasalahan yang terjadi pada UKM "Resep Iboe" dalam melakukan pengolahan dan penjualan kue kering tradisional khas Jember. Bagi pemilik usaha, pendampingan yang dilakukan oleh tim pengusul sangat membantu dalam kegiatan pengembangan usaha, terutama dalam hal inovasi produk, sistem pencatatan keuangan dan promosi menggunakan media digital. Hal ini juga terkait dengan masa pandemi Covid-19, dimana konsumen mulai sadar menerapkan less contact economy dalam hal melakukan pembelian maupun transaksi pembayaran.

\section{METODE}

Metode pelaksanaan dalam kegiatan ini adalah pelatihan dan pendampingan dalam pemanfaatan aplikasi keuanganan dan digital marketing kepada UKM "Resep Iboe". Pihak yang terlibat yakni dosen dan mahasiswa Universitas Jember. Platform yang digunakan adalah media online dalam memasarkan produk, mendampingi dalam penerapan teknologi informasi berbasis database berupa Google Form untuk pendataan konsumen dan pendampingan aplikasi SIAPIK untuk mengetahui laporan keuangan usaha, serta mendampingi dalam pembuatan brosur pemasaran digital menggunakan aplikasi imooji. Pihak yang terlibat berikutnya yakni pelaku UKM “Resep Iboe", yakni pemilik UMKM dan masyarakat setempat yang terdampak pandemi Covid-19 yang dipekerjakan, serta dinas lembaga terkait di Kabupaten Jember sebagai mitra dalam pemasaran.

Metode pelaksanaan produksi dilakukan melalui pelatihan dan pendampingan pengetahuan mengenai inovasi produk yang 
bernilai tambah dan bernilai jual pada aspek inovasi rasa, bentuk dan kemasan. Metode pelaksanaan dalam pendampingan pembukuan keuangan dengan memberikan pendampingan pembuatan sistem keuangan menggunakan aplikasi SIAPIK untuk mengetahui laporan keuangan usaha serta transaksi pembayaran digital menggunakan QRIS. Tujuannya agar jumlah produk yang telah terjual akan tercatat dan terdata, sehingga nantinya memudahkan dalam pembuatan pembukuan keuangan UKM. Metode yang dilakukan pada pelaksanaan pendampingan pemasaran melalui media online, yaitu pendampingan platform brosur pemasaran digital menggunakan imooji. Metode tersebut dilakukan sebagai media promosi dan juga penyampaian informasi terkait produk berupa aneka kue kering unik khas Jember. Selain itu, tim pendamping akan menerapkan strategi pemasaran online dengan cara menerapkan strategi give away dan juga paid promote pada media sosial.

Adapun metode pelaksanaan kegiatan Pengabdian kepada Masyarakat dengan skema Program Pengabdian Kemitraan Masyarakat dapat disusun sebagai berikut:

1. Metode Survei. Metode ini bertujuan untuk mengetahui secara langsung terhadap kondisi dan situasi mitra, baik berkenaan dengan lokasi.

2. Metode Sosialisasi dan presentasi materi. Adapun sosialisasi yang dilakukan di antaranya berkenaan dengan keilmuan manajemen terutama pada aspek pengelolaan pembukuan keuangan. Metode ini juga didukung dengan presentasi materi dari tim pengabdian sebagai narasumber. Materi-materi yang disajikan nantinya sesuai dengan bidang ilmu dan kompetensi masing-masing dari tim. Sosialisasi dan presentasi materi ini juga termasuk dalam hal bagaimana strategi promosi digital, yang tentunya dapat menciptakan peluang pasar tersendiri, baik di tingkat lokal, regional maupun nasional.

3. Metode Evaluasi, metode ini dilakukan untuk mengukur tingkat keberhasilan dari pada kegiatan yang dilaksanakan, yaitu pelatihan dan pendampingan sistem keuangan dan pemasaran digital dalam meminimalisir kontak pada saat pandemi Covid-19.

4. Metode Bimbingan. Metode ini tidak hanya dilakukan ketika kegiatan berlangsung, namun juga dilakukan pasca kegiatan, yang mana tim pengusul akan membuka konsultasi pasca pendampingan, hal ini merupakan bentuk konsistensi tim dalam melaksanakan kewajiban sebagai bagian dari Tridarma Perguruan Tinggi. Metode ini juga bertujuan sebagai keberlanjutan usaha

Tabel 1. Timeline Kegiatan

\begin{tabular}{|c|c|c|c|c|c|c|c|}
\hline \multirow{2}{*}{ No } & \multirow{2}{*}{ Kegiatan } & \multicolumn{6}{|c|}{ Bulan } \\
\hline & & 7 & 8 & 9 & 10 & 11 & 12 \\
\hline 1. & $\begin{array}{l}\text { Sosialisasi } \\
\text { program } \\
\text { kepada } \\
\text { sasaran } \\
\text { pengabdian }\end{array}$ & & & & & & \\
\hline 2. & $\begin{array}{l}\text { Pelaksanaan } \\
\text { Pendampingan } \\
\text { Pembukuan } \\
\text { Keuangan }\end{array}$ & & & & & & \\
\hline 3. & $\begin{array}{l}\text { Pelaksanaan } \\
\text { Pendampingan } \\
\text { Pemasaran } \\
\text { Digital }\end{array}$ & & & & & & \\
\hline 4. & $\begin{array}{l}\text { Menyusun } \\
\text { luaran artikel } \\
\text { ilmiah dan } \\
\text { video kegiatan }\end{array}$ & & & & & & \\
\hline 5. & $\begin{array}{l}\text { Monitoring dan } \\
\text { evaluasi }\end{array}$ & & & & & & \\
\hline 6. & $\begin{array}{l}\text { Tindak lanjut } \\
\text { pascaprogram }\end{array}$ & & & & & & \\
\hline 7. & $\begin{array}{l}\text { Menyusun } \\
\text { Laporan akhir }\end{array}$ & & & & & & \\
\hline
\end{tabular}

\section{HASIL DAN PEMBAHASAN}

Hasil kegiatan Program Pengabdian Kemitraan ini merupakan satu rangkaian pendampingan dan pelatihan berdasarkan masalah dan kebutuhan dalam rangka memberi alternatif solusi atas permasalahan UKM. Permasalahan pertama yang diidentifikasi di UKM "Resep Iboe" adalah pada proses produksi yang selama ini masih bersifat tradisional sehingga produksi yang dihasilkan masih kurang optimal dan membutuhkan inovasi. Berdasarkan hasil penelitian Kalil (2020), menyebutkan bahwa inovasi produk mempengaruhi kinerja UKM. Hasil penelitian menunjukkan bahwa kreativitas dan inovasi produk mampu meningkatkan kinerja usaha UKM secara positif dan signifikan baik secara parsial maupun simultan.

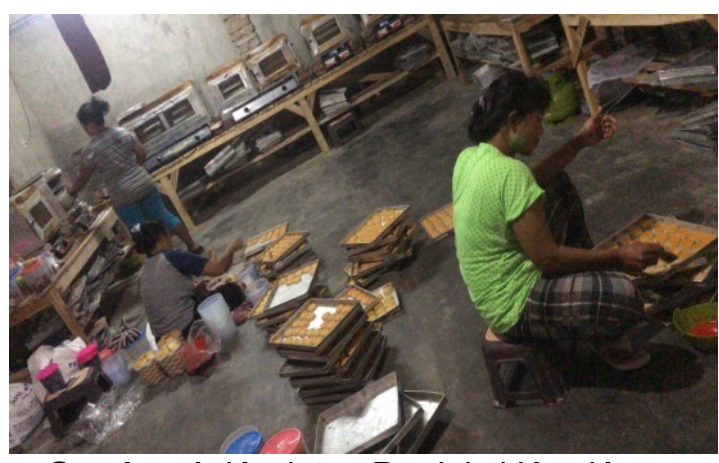

Gambar 1. Kegiatan Produksi Kue Kacang di UKM "Resep Iboe" 
Bagi pemilik ataupun pengelola UKM diharapkan untuk meningkatkan budaya kreativitas dan inovasi produk sehingga menghasilkan kinerja yang turut meningkat. Oleh karena itu, pada kegiatan Program Pengabdian Kemitraan ini dilakukan pendampingan pertama mengenai inovasi produk seperti bentuk, rasa, dan kemasan. Tim pengusul menghadirkan inisiator Paguyuban Kue Kacang Khas Jember yang memberikan sharing mengenai trend bentuk dan rasa yang saat ini digemari konsumen pada pendampingan inovasi produk UKM "Resep Iboe", sekaligus memberikan pelatihan inovasi kemasan berupa Hampers agar meningkatkan nilai tambah dan nilai jual dari kue kacang UKM "Resep Iboe".

Pada kegiatan pertama tersebut memberikan dampak pada produksi inovasi berupa bentuk kue kacang yang lebih variatif dengan menyesuaikan dengan bentuk kemasan, sehingga penempatan pada kemasan dapat tertata rapi dan estetik. Sedangkan, mengenai rasa kue kacang, menghasilkan adanya diversifikasi rasa kue kacang. Varian rasa tersebut seperti menambahkan ekstrak seperti pandan, coklat dan keju. Berkaitan dengan kemasan, yang mana berawal masih terbatas melayani penjualan secara grosir. Namun saat ini, telah hadir kemasan Hampers kue kacang yang menarik dan kekinian sebagai oleh-oleh maupun bingkisan kepada orang terkasih. Ada pun ketiga inovasi yang dihadirkan ini, dimulai dari varian bentuk, varian rasa, dan varian kemasan mampu meningkatkan penjualan Kue Kacang Khas Jember yang menjadi pelanggan setia, baik dari reseller, grosir, toko pusat oleholeh, atau pun konsumen langsung pecinta kue kacang.

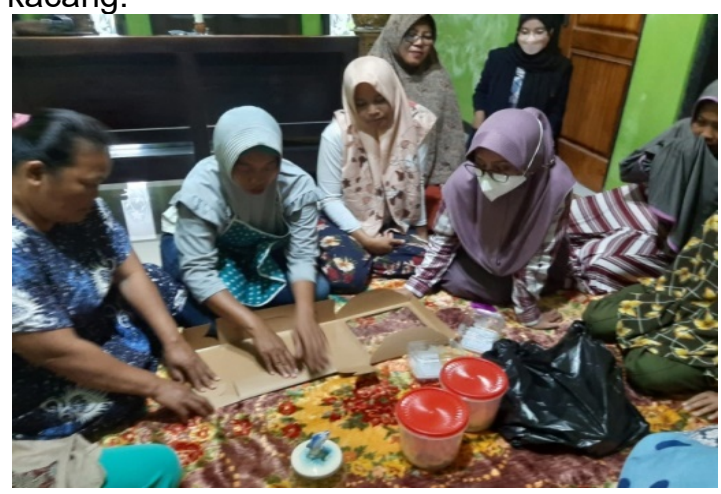

Gambar 2. Pelatihan dan Sharing Inovasi Produk Oleh Inisiator Paguyuban Kue Kacang Khas Jember di UKM "Resep Iboe"

Permasalahan kedua yang terjadi dalam UKM "Resep Iboe" yaitu tidak adanya pembukuan keuangan yang terstruktur. Hal ini dikarenakan kurangnya pengetahuan dari pemilik UKM terkait pembukuan keuangan, sehingga mengakibatkan produk yang telah terjual tidak tercatat dan terhitung sebagaimana mestinya. Selain itu, jumlah keuntungan bersih yang diperoleh tidak diketahui secara jelas. Informasi mengenai cara pencatatan transaksi keuangan usaha yang baik, mudah, namun sesuai dengan standar keuangan yang berlaku, menjadi tantangan tersendiri bagi para pelaku UKM, terutama pemahaman dan penggunaan Standar Akuntansi Keuangan Entitas Kecil, Mikro dan Menengah (SAK-EMKM) yang merupakan standar bagi pelaku UKM dalam mengukur kinerja keuangan usaha, pengembangan bisnis dan laporan keuangan yang bankable (Anjilni, 2020).

Tim pengusul Program Pengabdian Kemitraan melakukan pendampingan berupa pelatihan penggunaan aplikasi keuangan SIAPIK dan pendampingan transaksi pembayaran digital menggunakan QRIS. Pada kegiatan pelatihan dan pendampingan menghadirkan narasumber dari komunitas GenBI yang memahami proses pencatatan keuangan menggunakan SIAPIK dan pendampingan transaksi pembayaran digital QRIS.

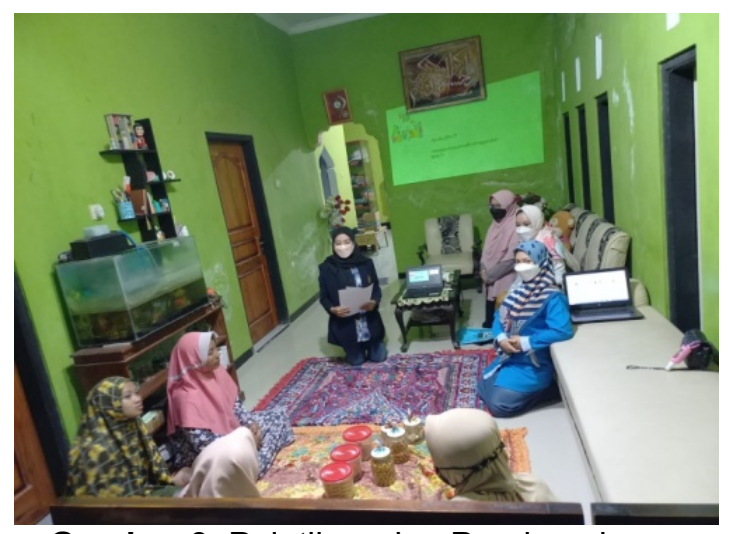

Gambar 3. Pelatihan dan Pendampingan

Pencatatan Keuangan SIAPIK dan Transaksi

Pembayaran Digital QRIS oleh Anggota Komunitas GenBI Jember

SIAPIK merupakan Sistem Aplikasi Pencatatan Informasi Keuangan, yang berguna mencatat transaksi keuangan dan laporan keuangan masing-masing pelaku usaha. Materi pembuatan laporan keuangan tidak mudah dipahami oleh para pelaku UKM di pedesaan, sehingga perlu pendampingan secara intensif. Pendampingan pembukuan keuangan digital SIAPIK pada UKM "Resep Iboe" disampaikan kepada karyawan yang bertanggung jawab terhadap pencatatan keuangan. Hal ini dilakukan agar lebih fokus pada sasaran. Selanjutnya proses pencataan 
dimulai dengan contoh-contoh tansaksi sederhana yang biasa dilakukan para pelaku UKM dengan menggunakan aplikasi SIAPIK.

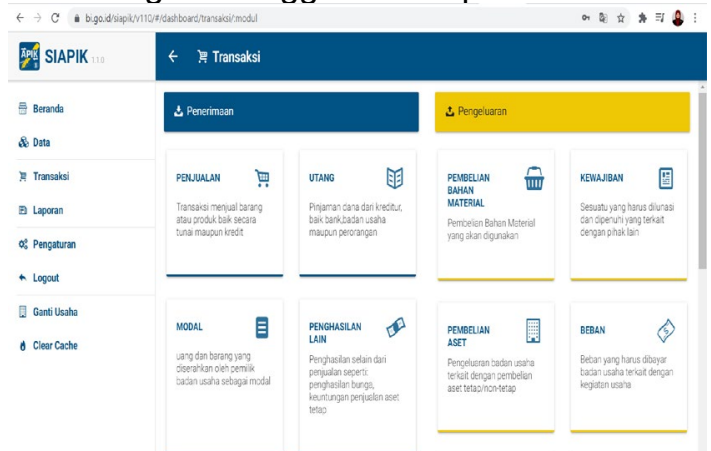

Gambar 4. Pencatatan Keuangan SIAPIK pada UKM "Resep Iboe"

Sedangkan QRIS merupakan salah satu alternatif transaksi masa kini yang sangat didukung langsung oleh Bank Indonesia untuk memudahkan seluruh masyarakat Indonesia, baik yang berposisi sebagai konsumen maupun sebagai pedagang dalam proses jual beli. Kelebihan dari QRIS antara lain yaitu memudahkan penjual tidak perlu menyiapkan uang kembalian, menghindari penjual dari uang palsu, menghemat waktu dengan waktu penerimaan uang realtime, dan untuk mendapatkan QRIS sendiri maka pedagang tidak dipungut biaya apapun, serta saat transaksi tidak terdapat potongan biaya administrasi.

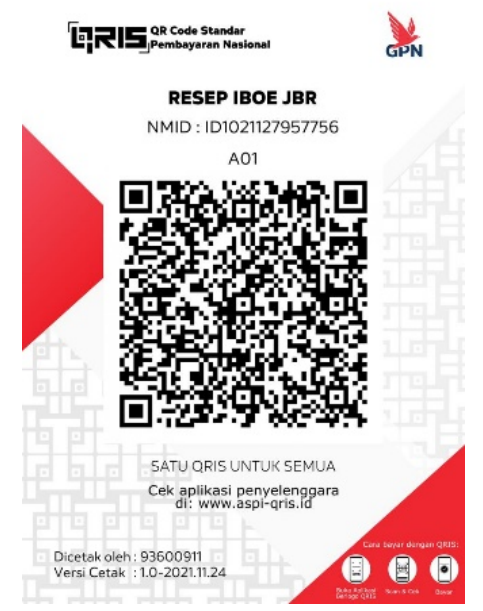

Gambar 5. Hasil Pendampingan Barcode Pembayaran Digital QRIS "Resep Iboe”

Pada kegiatan ini menghasilkan adanya pencatatan keuangan SIAPIK yang dilakukan langsung oleh pemilik "Resep Iboe". Selain itu, "Resep Iboe" telah memiliki barcode QRIS yang mampu memudahkan transaksi penjualan kue kering, khususnya bagi pembeli grosir. Pembeli grosir yang biasanya membeli hingga ratusan kotak kue yang langsung mendarangi tempat produksi, tidak perlu lagi membawa uang cash yang memiliki risiko tinggi. Risiko ini bukan hanya berbahaya karena kehilangan uang yang dicuri, jambret, atau pun lain sebagainya, namun yang terpenting adalah meminimalisir penularan virus Corona melalui pertukaran uang pada transaksi penjualan barang.

Permasalahan ketiga, yaitu akses pemasaran melalui promosi produk belum menyebar luas. Sedangkan di sisi lain UKM "Resep Iboe" diharuskan menyesuaikan dengan kondisi pandemi Covid-19 untuk menerapkan less contact economy, sehingga diperlukan pengembangan digitalisasi pemasaran melalui teknologi informasi. Perkembangan teknologi informasi berkembang dengan pesat. Sebagaian aktivitas Usaha Kecil dan Menengah (UKM) memanfaatkan teknologi informasi untuk menjalankan usahanya. Strategi komunikasi pemasaran yang tepat digunakan untuk bisa meraih pangsa pasar yang dituju, sehingga dapat meningkatkan penjualan (Pradiani, 2017). Wardhana (2015) menemukan bahwa strategi digital marketing berpengaruh hingga $78 \%$ terhadap keunggulan bersaing UKM dalam memasarkan produknya. Saat ini UKM "Resep Iboe" masih mengandalkan media sosial berupa grup whatsapss, facebook dan instagram. Seharusnya penjualan ditargetkan mampu mencapai wilayah yang lebih luas, namun saat ini produk hanya mampu dipasarkan di kota-kota terdekat dari tempat produksi yaitu Kabupaten Jember.

Berdasarkan permasalahan akses pemasaran dan promosi produk, maka tim pengusul Program Pengabdian Kemitraan mencoba melakukan pelatihan desain promosi kepada pengelola pemasaran UKM. Pelatihan desain promosi menggunakan aplikasi digital marketing berbasis android yaitu Imooji. Layanan Imooji dapat digunakan untuk membantu para pemula bisnis dalam memasarkan produknya (Irawan, et.al. 2020). Imooji merupakan platform digital sebagai sarana atau alat komunikasi dalam membuat interaktif digital brosur, katalog produk, promosi barang atau jasa, greeting cards, dan sebagainya. Dengan menggunakan Imooji, para pelaku usaha dapat dengan mudah menyasar target audiens melalui sosial media seperti Facebook dan Twitter melalui fitur share maupun aplikasi chatting seperti WhatsApp dan Line. Selain itu, juga tersedia QR Code untuk memudahkan target audiens yang disasar.

Pada kegiatan pengabdian ini, perwakilan UKM "Resep Iboe" antusias mengikuti dan menyimak penyampaian pelatihan imooji, mulai dari pendaftaran akun, 
unggah foto-foto produk dan usaha berdasarkan komponen 4P (Product, Place, Price dan Promotion). Pelaku usaha UKM "Resep lboe" merasa terkesan dengan berbagai fitur yang ditawarkan Imooji, karena kegiatan promosi lebih interaktif dengan biaya terjangkau, bahkan ada yang gratis. Selain itu, diketahui "Resep Iboe" banyak melakukan pemasaran melalui media Facebook dan Whatsapp. Pengiriman foto produk setiap hari dengan jumlah yang banyak menjadikan target konsumen terkadang merasa enggan untuk mengunduh, karena takut akan kehilangan memory pada HP. Hal ini berakibat pada gagalnya pemasaran. Aplikasi Imooji menjadi solusi alternatif dalam hal tersebut. Oleh sebab itu, hasil dari pelatihan dan pendampingan pembuatan booklet digital Imooji di UKM "Resep Iboe" adalah adanya pemasaran digital melalui Imooji yang dapat diakses pada tautan berikut:https://imooji.com/stage/v5/29NEB/770 76.

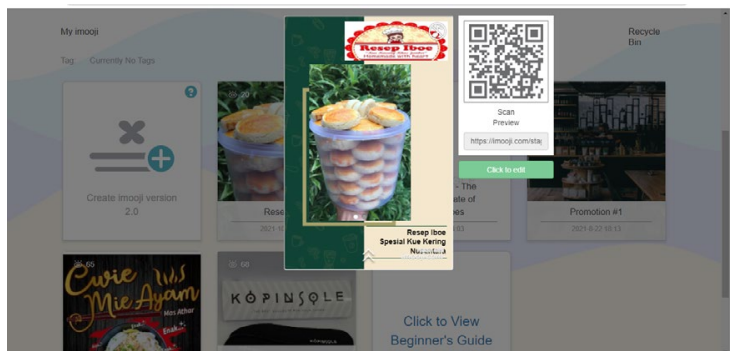

Gambar 6. Tampilan Imooji

Rencana tahapan selanjutnya yaitu melakukan pendampingan berkala terhadap pencatatan keuangan SIAPIK dan penerapan transaksi pembayaran QRIS, melakukan pendampingan selanjutnya berkaitan pengumpulan data consumer database dan pengecekan perkembangan view konsumen yang melihat booklet digital imooji.

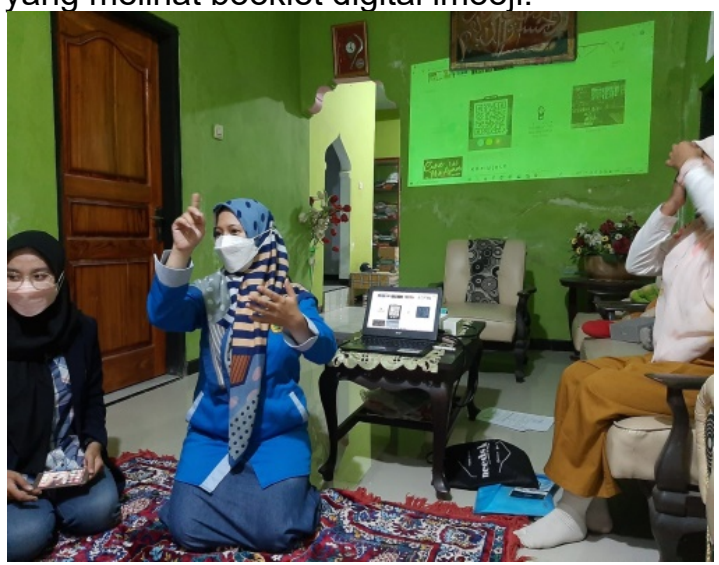

Gambar 7. Pendampingan Pembuatan Imooji

\section{SIMPULAN DAN SARAN}

Simpulan pada kegiatan Program Pengabdian Kemitraan pada UKM "Resep Iboe" adalah adanya partisipasi pelaku usaha UKM "Resep Iboe" selaku mitra dalam pelaksanaan kegiatan yaitu keterlibatan mengikuti pelatihan dan pendampingan inovasi produk, pencatatan keuangan digital dan transaksi pembayaran, serta pendampingan pemasaran digital menggunakan aplikasi imooji. Kegiatan dimulai dengan sosialisasi kegiatan pendampingan, dilanjutkan dengan pelatihan inovasi produk (bentuk, rasa, dan kemasan), pelatihan transaksi keuangan (SIAPIK dan QRIS) dan pelatihan desain promosi digital marketing (imooji).

Tim pengabdian menemui kendala dalam pelaksanaan kegiatan pengabdian, diantaranya, transfer pengetahuan dan keterampilan menggunakan sistem keuangan dan pemasaaran digital dirasa menyulitkan karena beberapa karyawan masih melakukan penyesuaian dengan teknologi. Oleh sebab itu, penyampaian pelatihan secara teknis dilakukan melalui perwakilan karyawan yang masih berusia muda dan dirasa mampu menerapkan hasil pelatihan sebagai solusi alternatif. Hal ini juga menyimpulkan bahwa, kegiatan pengabdian ini juga berbasis kelompok pada pendampingan kewirausahaan, kelembagaan dan manajemen pemasaran dalam mendukung pengembangan usaha.

Tindak lanjut pasca program dari kegiatan ini sebagai bentuk saran adalah menjadikan lokasi pelaksanaan pengabdian sebagai mitra edukasi kewirausahaan, upaya bantuan pendampingan alat produksi, pendampingan manajemen keuangan dan media pemasaran platform digital marketing imooji.

\section{UCAPAN TERIMAKASIH}

Ucapan terima kasih disampaikan kepada:

1. Pihak Universitas Jember, dalam hal ini adalah LP2M yang telah memfasilitasi program pengabdian kemitraan ini

2. Fakultas Pertanian, Universitas Jember yang telah memberi ijin kegiatan pengabdian kepada masyarakat.

3. Para narasumber yang telah bersedia untuk mentransferkan ilmu pengetahuan dan keterampilannya untuk mitra UKM "Resep Iboe"

4. Pemilik dan karyawan UKM "Resep Iboe" yang telah menyediakan tempat pelatihan dan pendampingan UKM. 
DAFTAR RUJUKAN

Amri, A. (2020). Dampak Covid-19 Terhadap UMKM di Indonesia. Jurnal Brand, 2(1), 123-130

Irawan, P., Prilianti \& Melany. (2020). Pemberdayaan Usaha Kecil Menengah (UKM) Melalui Implementasi Ecommerce di Kelurahan Tlogomas. Jurnal SOLMA, 09 (01), 33-44

Kalil \& Aenurohman (2020). Dampak Kreativitas dan Inovasi Produk terhadap Kinerja UKM di Kota Semarang. Jurnal Penelitian Humaniora, 21 (1), 69-77.

Marlina, L., Sumarni, R., \& Mundzir, A. (2018). Edukasi Literasi Finansial melalui Aplikasi Si Apik pada Masyarakat Desa Santanamekar Tasikmalaya. Memperkuat Produktivitas untuk Ketahanan Ekonomi Nasional. 2, pp. 972-980. Jakarta: Relawan Jurnal Indonesia

Nurlinda \&Sinuraya, J. (2020). Prosiding Seminar Akademik Tahunan IImu Ekonomi dan Studi Pembangunan. Prosiding Seminar Akademik Tahunan IImu Ekonomi dan Studi Pembangunan 2020, 160-175.

Pradiani, T. (2017). Pengaruh Sistem Pemasaran Digital Marketing Terhadap Peningkatan Volume Penjualan Hasil Industri Rumahan. Jurnal Jibeka, 11(2), 46-53

Wardhana, Aditya. (2015). Strategi Digital Marketing dan Implikasinya pada Keunggulan Bersaing UKM di Indonesia. Seminar Nasional Keuangan dan Bisnis IV (pp. 327-337). Universitas Pendidikan Indonesia 